\title{
Cadmium, silicon and nutrient accumulation by maize plants grown on a contaminated soil amended with a diatomaceous Earth fertilizer
}

\section{Josévaldo Ribeiro Silva ${ }^{1}$ (D) Venâncio de Lima Veloso ${ }^{1}$ (D) Fernando Bruno Vieira da Silva ${ }^{1}$ (i) Clístenes Williams Araújo do Nascimento ${ }^{1^{*}}$ [D}

${ }^{1}$ Departamento de Agronomia, Universidade Federal Rural de Pernambuco (UFRPE), 52171-900, Recife, PE, Brasil. E-mail: cwanascimento@yahoo.com. ${ }^{*}$ Corresponding author.

ABSTRACT: Given that cadmium (Cd) poses high persistence in the environment and toxicity to humans, strategies to either decrease or avoid Cd entry in the trophic chain are fundamental to secure food safety. Here we assessed the effects of applying rates of Si as a diatomaceous Earth-based fertilizer on the amelioration of Cd toxicity towards maize plants grown on soil with or without pH correction. Besides determining Si and Cd concentrations, we also evaluated plant accumulation of nutrients ( $N$, P, K, Ca, Mg, Fe, $\mathrm{Mn}, \mathrm{Cu}$, and $\mathrm{Zn}$ ) as a function of Si doses applied to the soil. Results showed that both the Si application and the liming had a positive effect on biomass and nutrient uptake, but the Si effect on plants' performance took place irrespectively to the soil pH. Silicon ameliorated $C d$ phytotoxicity in both limed and unlimed soils by decreasing Cd concentration in shoots and improving biomass yield and plant nutrition. Silicon alleviation of Cd-inhibitory effects on plants was more effective in the unlimed soil owing to the higher Cd availability in acidic soils. Also, taking into account the reduced transfer of Cd to shoots driven by Si, lower Cd accumulation in maize grains is likely, with implications to food safety. So, further studies on field conditions are warranted.

Key words: heavy metals, plant nutrition, Zea mays, Cd, phytotoxicity.

Acúmulo de cádmio, silício e nutrientes por plantas de milho cultivadas em solo contaminado e adubado com fertilizante terra diatomáceas

RESUMO: Considerando que o cádmio (Cd) apresenta alta persistência no ambiente e toxicidade aos seres humanos, estratégias para diminuir ou evitar a entrada de Cd na cadeia trófica são fundamentais para garantir a segurança alimentar. Neste contexto, avaliamos os efeitos de silício (Si) aplicado como fertilizante a base de terra diatomácea na amenização da toxicidade do Cd em milho cultivado em solo contaminado, com e sem correção de pH. Além de determinar as concentrações de Si e Cd, o acúmulo de nutrientes nas plantas ( $N$, P, K, $\mathrm{Ca}, \mathrm{Mg}, \mathrm{Fe}, \mathrm{Mn}$, Cu e $\mathrm{Zn}$ ) em função das doses de Si aplicadas ao solo foi avaliado. Os resultados mostraram que tanto a calagem quanto o Si tiveram efeitos positivos na biomassa e na absorção de nutrientes, mas o efeito do Si no desenvolvimento das plantas foi independente da reação do solo. O Si reduziu a fitotoxidade por Cd em ambos os solos, corrigidos e não corrigidos, diminuindo a concentração de Cd na parte aérea. A amenização da toxicidade de Cd foi mais efetiva em solos sem correção, devido à maior disponibilidade de Cd em solos ácidos. Os beneficios da aplicação de Si sobre a produção de biomassa, composição mineral e fitotoxidade do Cd foram observados em plantas cultivadas em solos com e sem correção. Considerando a transferência reduzida de Cd para a parte aérea promovida pelo Si, é provável que ocorra menor acúmulo de Cd nos grãos de milho, com implicações para a segurança alimentar.

Palavras-chave: metais pesados, nutrição de planta, Zea mays, Cd, fitotoxidade.

\section{INTRODUCTION}

Cadmium $(\mathrm{Cd})$ is one of the most toxic metals for humans, plants, and animals (ATSDR, 2017). Anthropogenic activities such as mining, waste disposal, and the use of fertilizers and agrochemicals have increased $\mathrm{Cd}$ availability in soils. The entry of $\mathrm{Cd}$ into the food chain is facilitated by the metal high mobility in both soils and plants, which, in turn, reduces the uptake of nutrients and water, inhibits photosynthesis and alters the expression of genes and proteins. Since food consumption is the main route of human exposure to contaminants, high Cd mobility is a threat to food safety (LAMB et al., 2016). Therefore, strategies that aim to decrease the mobility and consequent transfer of $\mathrm{Cd}$ from soil to plants are essential to reduce the risk of $\mathrm{Cd}$ food chain contamination. 
Silicon (Si) has beneficial effects on growth, development, and yield of various crops (NASCIMENTO et al., 2019). The element is absorbed by the roots in the form of monosilicic acid $\left(\mathrm{H}_{4} \mathrm{SiO}_{4}\right)$ and transported to aboveground parts, where $\mathrm{Si}$ deposition occurs as amorphous silica $\left(\mathrm{SiO}_{2}\right.$. $\mathrm{nH}_{2} \mathrm{O}$ ) in the leaf epidermis. Silica in plant tissues has been related to reduction of plant tipping, increased tolerance to fungal and insect attacks, and water deficit (WANG, Y. et al., 2019).

Silicon also plays a role in alleviating heavy metal stress in plants. For example, silicon addition to nutrient solution reduced by $20 \%$ the translocation of $\mathrm{Cd}$ from roots to maize shoots, with effects on damage reduction to the photosynthetic apparatus (SILVA et al., 2017). Rice plants (Oryza sativa) cultivated under $\mathrm{Cd}$ stress and Si-treated showed an increase in chlorophyll content, photosynthetic rate, and growth (REHMAN et al., 2019). Silicon application to soil had a positive effect on the biomass production of pigeon pea plants grown under $\mathrm{Cd}$ and $\mathrm{Zn}$ stress; besides, silicon reduced uptake and translocation of these metals to the shoots (GARG \& SINGH, 2018). Cadmium is also able to change the plant mineral composition; therefore, silicon ability to improve uptake, transport, and nutrient distribution in plants may play a role in $\mathrm{Cd}$ stress tolerance (SILVA et al., 2017).

The soil $\mathrm{pH}$ is also an important factor in determining $\mathrm{Cd}$ availability to plants. Maize plants grown in limed soil had higher biomass yield and lower $\mathrm{Cd}$ accumulation compared to plants on the unlimed soil (CUNHA \& NASCIMENTO, 2009). SHAREEF et al. (2016) reported that increasing soil $\mathrm{pH}$ significantly diminished the accumulation of $\mathrm{Cd}$ in roots, shoots, and grains of maize. KIRKHAM (2006) data revealed that both the increased soil $\mathrm{pH}$ and the Si amendment were efficient in reducing the $\mathrm{Cd}$ availability in soil.

Si-mediated immobilization of $\mathrm{Cd}$, which can occur both in the soil and in the plant itself, can potentially reduce the risks of $\mathrm{Cd}$ accumulation by crops and, therefore, be valuable in the contaminated soils management and reduction of risks associated with food chain contamination. In this scenario, studying the effects of $\mathrm{Si}$ on $\mathrm{Cd}$ phytotoxicity attenuation should involve assessing the effects of $\mathrm{Si}$ on both the plant and soil. Our objective was to evaluate the effect of Si doses using a diatomaceous Earth source on the biomass production and uptake of $\mathrm{Cd}, \mathrm{Si}$, and nutrients by maize plants (Zea mays L.) grown on soil contaminated with cadmium. Diatomaceous earth is reported to optimize soil fertility and plant nutrition through improved water, physical and chemical soil properties (NASCIMENTO et al., 2019). Since $\mathrm{pH}$ is probably the most crucial isolated soil factor determining Cd availability to plants, we studied $\mathrm{Si}$ effects in the same soil with and without $\mathrm{pH}$ correction.

\section{MATERIALS AND METHODS}

The soil chemical characteristics of the Ultisol used in the experiment were analyzed and displayed the following results: $\mathrm{pH}_{\mathrm{H} 2 \mathrm{O}} 4.6 ; 3.16 \mathrm{mg}$ $\mathrm{dm}^{-3} \mathrm{P} ; 6.41 \mathrm{cmolc} \mathrm{dm}^{-3} \mathrm{H}^{+}+\mathrm{Al}^{3+} ; 0.25$ cmolc dm $\mathrm{dm}^{-3}$ $\mathrm{Al}^{3+} ; 0.01$ cmolc $\mathrm{dm}^{-3} \mathrm{Na}^{+} ; 0.01$ cmolc $\mathrm{dm}^{-3} \mathrm{~K}^{+}$; 0.80 cmolc dm ${ }^{-3} \mathrm{Ca}^{+2} ; 0.60$ cmolc $\mathrm{dm}^{-3} \mathrm{Mg}^{+2} ; 13 \mathrm{~g}$ $\mathrm{kg}^{-1}$ organic carbon; $340 \mathrm{~g} \mathrm{~kg}^{-1}$ clay; $32 \mathrm{~g} \mathrm{~kg}^{-1}$ silt; and $628 \mathrm{~g} \mathrm{~kg}^{-1}$ sand. Cadmium concentration in soil $\left(0.7 \mathrm{mg} \mathrm{kg} \mathrm{kg}^{-1}\right)$ was determined after acid extraction (USEPA, 2002). The Si available concentration of 2.3 $\mathrm{mg} \mathrm{kg}{ }^{-1}$ was obtained after extraction wit acetic acid (KORNDÖRFER et al., 1999).

We applied $\mathrm{Si}$ under two soil $\mathrm{pH}$ conditions: original ( $\mathrm{pH} 4.6)$ and corrected to $\mathrm{pH}$ 6.5. The soil was corrected using calcium carbonate $\left(\mathrm{CaCO}_{3}\right)$ and magnesium oxide $(\mathrm{MgO})$ with a $\mathrm{Ca}: \mathrm{Mg}$ molar ratio of $3: 1$, based on a previous acidity neutralization curve. Then, Cd was applied to the soil at the concentration of $10 \mathrm{mg} \mathrm{kg}^{-1}$ as cadmium chloride $\left(\mathrm{CdCl}_{2} \cdot \mathrm{H}_{2} \mathrm{O}\right)$; this concentration was chosen based on previous studies that identified a soil $\mathrm{Cd}$ toxic critical level for maize growing (CUNHA et al., 2008). After ten days of $\mathrm{Cd}$ contact with soil, $\mathrm{Si}$ was applied as a granular fertilizer (2-5 $\mathrm{mm})$ derived from diatomaceous earth (AgrisilicaTM, Agripower Australia Limited), with a total concentrations of $26 \% \mathrm{Si}, 2 \% \mathrm{Ca}, 1 \% \mathrm{Mg}$, and $1 \% \mathrm{Fe}$ (NASCIMENTO et al., 2019). Treatments consisted of doses equivalent to $0,100,150,200$, $300 \mathrm{mg} \mathrm{kg}^{-1}$ of Si (equivalent to 200, 300, 400, and $600 \mathrm{~kg} \mathrm{ha}^{-1}$ of $\mathrm{Si}$ ), mixed up in the total soil volume, homogenized, and incubated for ten days at $80 \%$ of the maximum water retention capacity before maize sowing.

The experiment was disposed in a randomized block design arranged in a $2 \times 5$ factorial scheme (2 soil pHs and $5 \mathrm{Si}$ doses), with three replicates. Soil fertilization was done simultaneously with the application of $\mathrm{Si}$, at the rates of $50,400,150$ and $40 \mathrm{mg} \mathrm{dm}^{-3}$ of $\mathrm{N}, \mathrm{P}, \mathrm{K}$, and $\mathrm{S}$, respectively, applied as $\left(\mathrm{NH}_{4}\right)_{2} \mathrm{SO}_{4}$ and $\mathrm{KH}_{2} \mathrm{PO}_{4}$. Micronutrients were also added as follow $\left(\mathrm{mg} \mathrm{dm}^{-3}\right)$ : 3.7 of $\mathrm{Mn}\left(\mathrm{MnCl}_{2} \cdot 4 \mathrm{H}_{2} \mathrm{O}\right)$; 4 of $\mathrm{Zn}\left(\mathrm{ZnSO}_{4} .7 \mathrm{H}_{2} \mathrm{O}\right) ; 1.3$ of $\mathrm{Cu}\left(\mathrm{CuSO}_{4}\right), 1.6$ of $\mathrm{Fe}\left(\mathrm{FeSO}_{4} \cdot 7 \mathrm{H}_{2} \mathrm{O}\right)$; and 0.15 of $\mathrm{Mo}\left(\mathrm{Na}_{2} \mathrm{MoO}_{4} \cdot 2 \mathrm{H}_{2} \mathrm{O}\right)$.

Maize seeds (Zea mays L.) were sown 
directly in the pot and, ten days after germination, only one plant was maintained until the end of the 30 days cultivation period. The soil in the pots was maintained at $80 \%$ of soil water-holding capacity by daily watering with distilled water. At the end of cultivation, shoots and roots were collected, washed in tap and distilled water, and oven-dried at $70{ }^{\circ} \mathrm{C}$ for $72 \mathrm{~h}$; biomass was then measured and tissues were ground to plant chemical analyses.

The concentrations of $\mathrm{Cd}, \mathrm{Ca}, \mathrm{Mg}, \mathrm{Cu}, \mathrm{Mn}$ and $\mathrm{Zn}$ in the digestion extract $\left(\mathrm{HClO}_{4}: \mathrm{HNO}_{3}, 1: 3\right.$ $\mathrm{v} / \mathrm{v}$ ) were determined by optical emission spectrometry (ICP-OES) (Perkin-Elmer/ICP-OES 7000), while P was obtained by photocolorimetry and $\mathrm{K}$ by flame photometry. The $\mathrm{N}$ concentration was determined in a sulfuric extract (SILVA et al., 2009). For Si determination, the plant samples were digested using hydrogen peroxide and sodium hydroxide in an autoclave. The $\mathrm{Si}$ in the extracts was measured by photocolorimetry at a wavelength of $410 \mathrm{~nm}$ (NI 2000UV, Nova Instruments, Brazil), using ammonium molybdate as a complexing agent (KORNDÖRFER et al., 2004).

The main and interaction effects were analyzed by applying ANOVA (F test). Correlation and regression analyses $(p \leq 0.05)$ were used to investigate the relationship of Si rates applied to the soil with biomass yield and plant concentrations of $\mathrm{Si}, \mathrm{Cd}$, and nutrients. All statistical analyses were accomplished with the software Statistica 10.1.

\section{RESULTS AND DISCUSSION}

Biomass production

The correlations between biomass yield and $\mathrm{Si}$ concentration in shoots were highly significant ( $\mathrm{pH} 4.6, \mathrm{r}=0.98^{* *}$ and $\mathrm{pH} 6.5, \mathrm{r}=0.94^{*}$ ). The large $\mathrm{Si}$ uptake by gramineous species, such as maize, sugarcane, rice, and wheat, is one of the most known effects of $\mathrm{Si}$ on plants. Also, some studies showed that adding Si to Cd-contaminated soil enhanced biomass of maize plants (CUNHA \& NASCIMENTO, 2009; VACULÍK et al., 2012). There was an interaction between the $\mathrm{Si}$ doses and the $\mathrm{pH}$ values on shoots and roots biomass production ( $p \leq 0.01)$; although, Si doses increased plant biomass regardless of the soil $\mathrm{pH}$. Plants cultivated in the soil with pH 6.5 had higher Si concentration, but the increment in Si uptake was proportionally higher for plants cultivated in the lower $\mathrm{pH}$ (Figure 1A). Soil $\mathrm{pH}$ correction and hence higher roots growth is a cause for increased Si and nutrient uptake as either shoot and roots biomass were doubled by liming (Figure 1A and 1B). However, it is clear that the higher the Si concentration in soil, the higher the biomass yield; therefore, the increased plant biomass was likely a combination of $\mathrm{Si}$ supply and $\mathrm{Si}$ alleviation of Cd stress.

Regarding roots biomass, we observed a distinct behavior for limed and non-limed soils. A linear effect of $\mathrm{Si}$ doses on roots biomass of plants
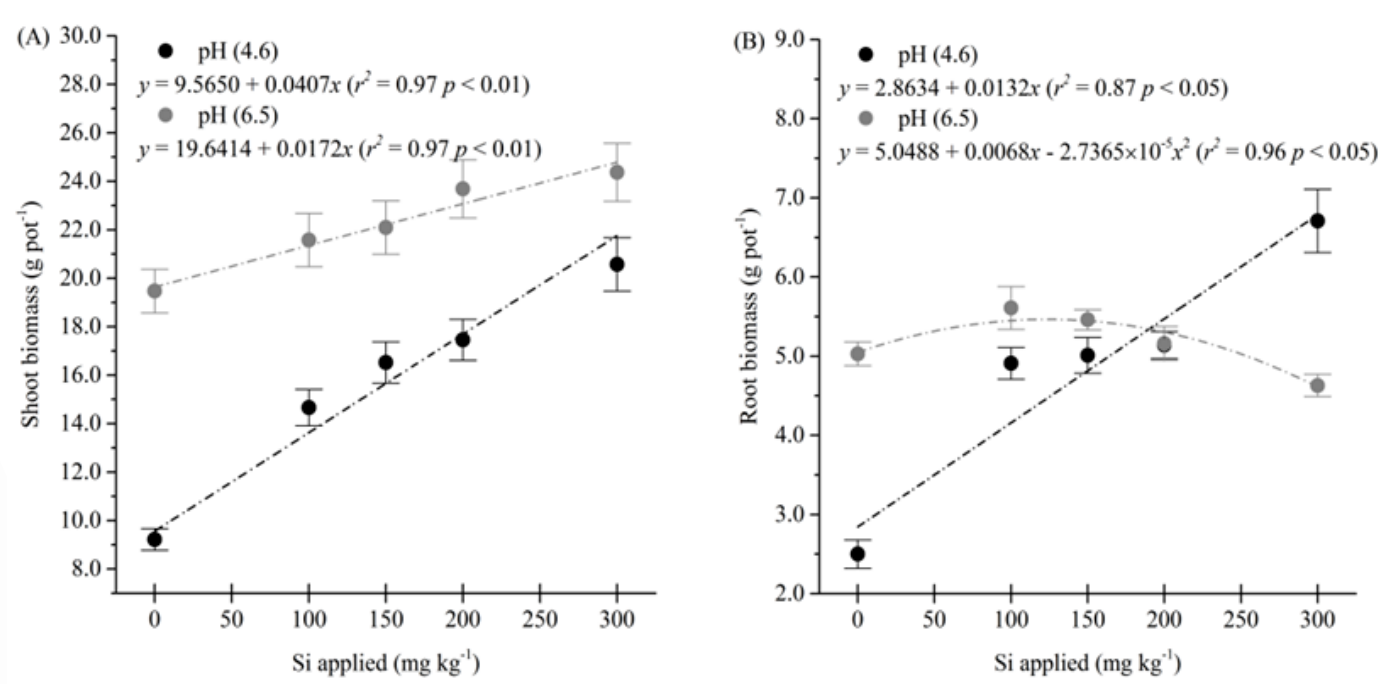

Figure 1 - Biomass production of maize shoot (A) and root (B) on an $\mathrm{Cd}$ - contaminated soil with or without $\mathrm{pH}$ correction as a function of silicon doses applied to soil. 
grow on the acidic soil (Figure 1B) suggested that $\mathrm{Si}$ alleviation of $\mathrm{Cd}$-inhibitory effects on maize plants is less effective in soils with higher $\mathrm{pH}$, in which carbonates can partially precipitate cadmium. It is well known that soil acidity is one of the main factors affecting Cd bioavailability, with higher Cd mobility in acidic soils (YU et al., 2016). Soil liming can reduce the availability of $\mathrm{Cd}$ by up to $76 \%$ (WANG et al., 2014), which along with Si effects on Cd phytotoxicity is responsible for the lower metal damage and higher roots biomass reported in the limed soil (Figure 1B).

\section{Accumulation of silicon and cadmium by plants}

Silicon concentration in shoot and roots showed an interaction $(p \leq 0.01)$ with Si doses and
$\mathrm{pH}$ values. Accumulation of Si had a linear response, except for roots in the corrected soil (Figure 2A and $2 \mathrm{~B}$ ), which is in line with root biomass response in this soil condition (Figure 1B). Both Si concentrations were higher in plants growing on the acidic soil. Decreased $\mathrm{Si}$ accumulation with an increase of $\mathrm{pH}$ is a likely result of Si lower solubility in the soil as dissociation of silicic acid $\left(\mathrm{H}_{4} \mathrm{SiO}_{4}\right)$ is strongly pH-dependent ( $\mathrm{YU}$ et al., 2016). Therefore, the lower Si removal from the corrected soil can be related to the monosilicic acid dissociation into $\mathrm{H}_{3} \mathrm{SiO}_{4}^{-}$, which is specificallyadsorbed onto iron and aluminum oxides, reducing the Si availability to plants (KEEPING et al., 2017).

Together with the soil $\mathrm{pH}$ effects previously discussed, the relationship between $\mathrm{Si}$
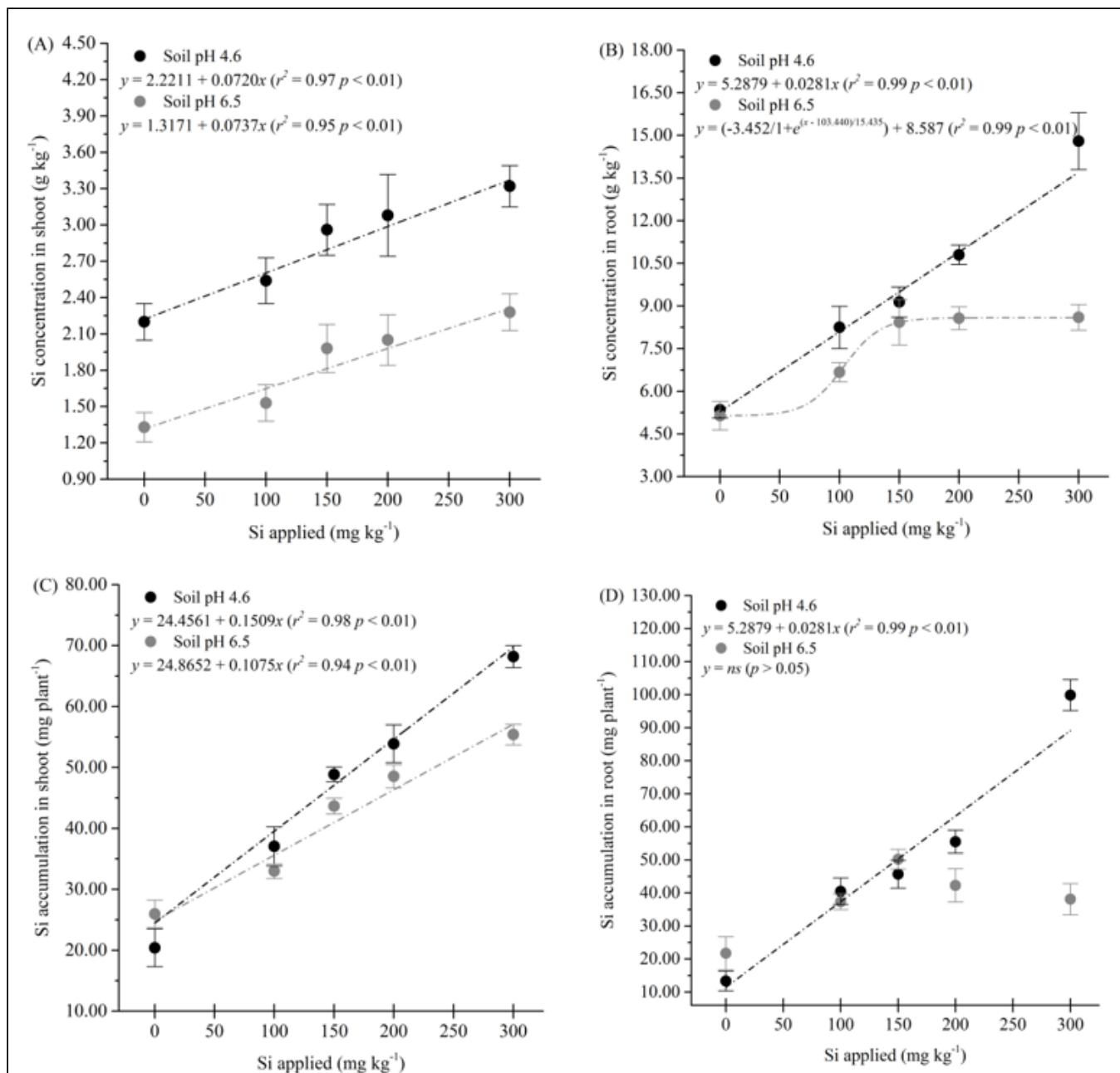

Figure 2 - Silicon concentration (A and B) and accumulation (C and D) in shoot and root of maize (Zea mays) grown on an $\mathrm{Cd}$ - contaminated soil with or without $\mathrm{pH}$ correction as a function of silicon doses applied to soil. 
solubility and soil $\mathrm{pH}$ seems to be a significant factor accounting for Cd concentration in our plants. At both $\mathrm{pH}$ conditions, shoot $\mathrm{Cd}$ concentrations decreased linearly with increasing $\mathrm{Si}$ doses (Figure $3 \mathrm{~A}$ ). The reduced $\mathrm{Cd}$ concentrations in shoots rely not only on the decreased bioavailability of the metal in Sitreated soils but also on the $\mathrm{Cd}$ retention in roots and avoidance of root-to-shoot translocation (CUNHA \& NASCIMENTO et al., 2009). For instance, VACULÍK et al. (2012) reported the development of an endodermal barrier in maize roots treated with $\mathrm{Si}$ that was correlated with Cd concentration in plants. Also, CUNHA \& NASCIMENTO (2009) suggested that the silica deposition visualized in the endodermis and pericycle of roots played a role in the maize tolerance to Cd stress.

The increase of both $\mathrm{Cd}$ and $\mathrm{Si}$ concentrations in roots of plants grown on the acidic soil (Figure 3B) suggested that diminished $\mathrm{Cd}$ translocation to shoots relied on $\mathrm{Cd}-\mathrm{Si}$ complexation in roots. This is confirmed by the ratio between $\mathrm{Cd}$ accumulated in shoots/Cd accumulated in roots, which decreased with the doses of $\mathrm{Si}$ applied to the soil (Figure 4). Conversely, for the limed soil, Cd$\mathrm{Si}$ precipitation in soil was probably the main factor decreasing $\mathrm{Cd}$ concentration in roots; although, $\mathrm{Si}$ still played a role in reducing $\mathrm{Cd}$ transfer to shoots. It is worth pointing out that roots were more abundant in the limed soil than in the acidic soil (Figure 1B), which explains the higher uptake of $\mathrm{Cd}$ and $\mathrm{Si}$ in these plants.

\section{Accumulation of nutrients by plants}

The regression analyses showed a significant and positive effect of the $\mathrm{Si}$ doses on the nutrients $\mathrm{N}, \mathrm{K}, \mathrm{Ca}, \mathrm{Mg}, \mathrm{Fe}, \mathrm{Mn}, \mathrm{Cu}$, and $\mathrm{Zn}$ accumulated in maize shoots, irrespective of soil $\mathrm{pH}$ (Figure 5). Phosphorus was the only nutrient not significantly affected by $\mathrm{Si}$ application to soil (Figure 5B). Other studies have shown that high rates of Si applied to soil can diminish $\mathrm{P}$ uptake owing to antagonistic effects between $\mathrm{H}_{2} \mathrm{PO}_{4}^{-}$and $\mathrm{H}_{3} \mathrm{SiO}_{4}^{-}$ (NASCIMENTO et al., 2019). Also, Si can increase $\mathrm{P}$ solubility in soil solution, which in turn can have an indirect effect on $\mathrm{Cd}$ precipitation in soil and roots as cadmium phosphate $\left[\mathrm{Cd}_{3}\left(\mathrm{PO}_{4}\right)_{2}\right]$. Indeed, $\mathrm{P}$ and $\mathrm{Cd}$ negative correlation in the shoot $\left(-0.65^{* *}\right)$ indicates that precipitation might have taken place.

As expected, owing to the higher roots biomass and hence greater nutrient uptake, macronutrient concentrations were, in general, higher in the limed soil (Figure 5), but Si addition improved nutrient accumulation regardless of soil $\mathrm{pH}$ condition. Silicon might enhance the efficient use of $\mathrm{N}$ by increasing its concentration in plants; increases in the accumulation of $\mathrm{K}, \mathrm{Ca}$, and $\mathrm{Mg}$ driven by $\mathrm{Si}$ have
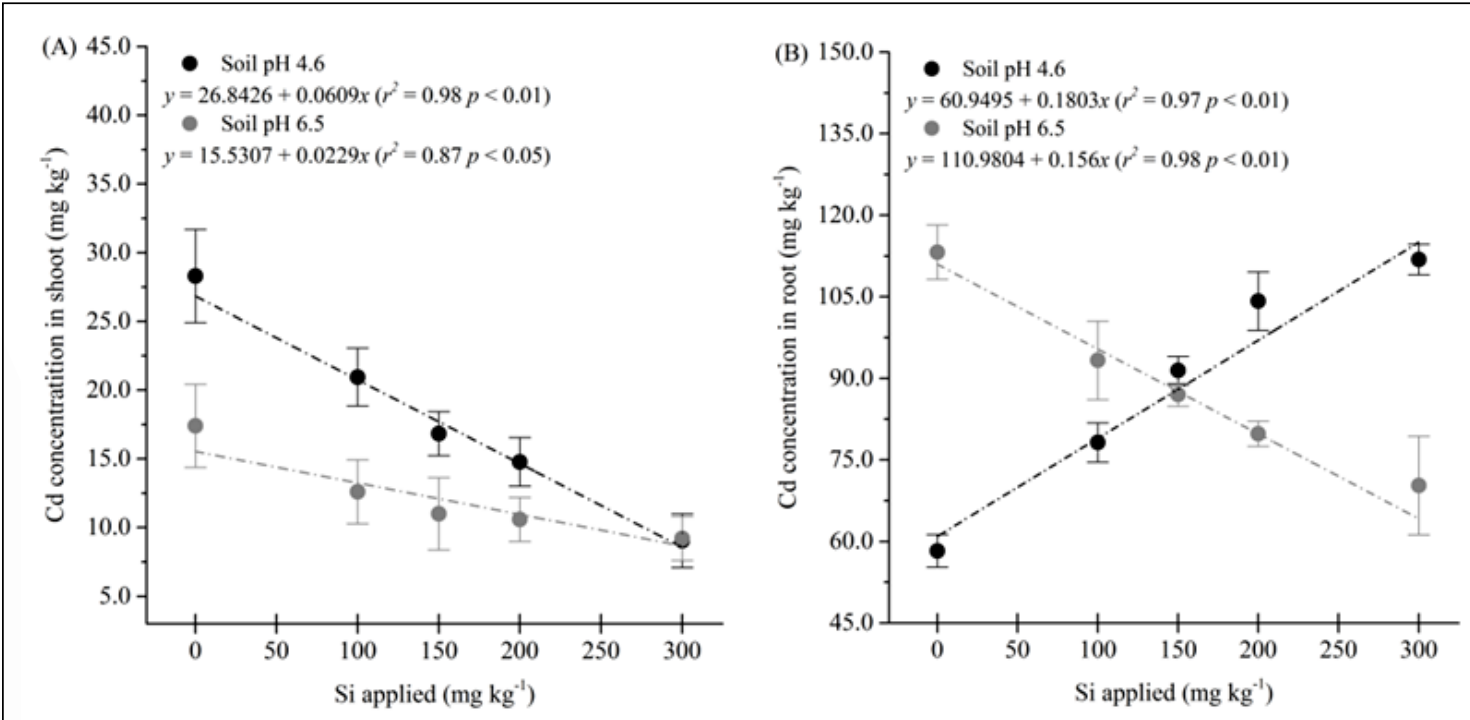

Figure 3 - Cadmium concentration in shoot (A) and root (B) of maize (Zea mays) grown on an Cd-contaminated soil with or without $\mathrm{pH}$ correction as a function of silicon doses applied to soil.

Ciência Rural, v.51, n.2, 2021. 


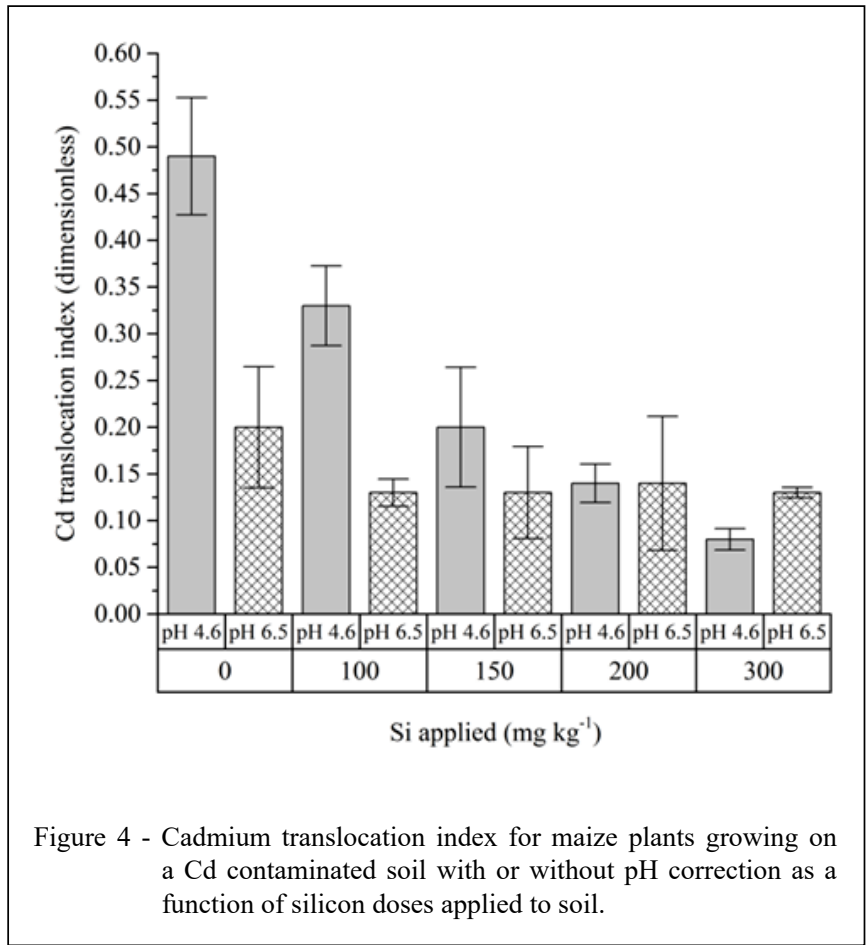

also been reported for several crops (NASCIMENTO et al., 2019).

The plant nutrition improvement reported here can be due not only to $\mathrm{Si}$ effects on nutrient efficiency use, but also on the role that Si plays on $\mathrm{Cd}$ stress. The root plasma membrane is the primary barrier to Cd uptake, as well as the first target for metal toxicity. Cadmium can replace $\mathrm{Ca}^{+2}$ and affect membrane integrity. Besides, Cd can lead to modification of plasma membrane $\mathrm{H}^{+}$-ATPase activity, which could diminish the gradient of protons across the membrane and hence decrease nutrient uptake. Therefore, the role of $\mathrm{Si}$ in maintaining membrane integrity is essential to prevent $\mathrm{Cd}$ uptake and to sustain ionic homeostasis of root cells (JANICKARUSSAK et al., 2012).

In contrast to macronutrients, an opposite trend with higher accumulation of $\mathrm{Fe}, \mathrm{Mn}, \mathrm{Zn}$, and $\mathrm{Cu}$ in plants cultivated on the acidic soil was observed (Figure 5F to 5I). Cationic micronutrients decrease in availability as $\mathrm{pH}$ rises; for example, $\mathrm{Zn}, \mathrm{Cu}$, and $\mathrm{Mn}$ available concentrations in soil decrease 100 fold with every one unit increase in pH (PALMER et al., 2009). Our data showed that Si addition to both limed and non-limed soils caused an increase in micronutrient accumulation (Figure 5). Antagonism for plant uptake between $\mathrm{Cd}^{+2}$ and cationic micronutrients is well known. Metal uptake relies mainly on a ubiquitous family of divalent metals transporters that mediates $\mathrm{Fe}, \mathrm{Zn}, \mathrm{Mn}$, and Ni uptake from soil (GONZÁLEZGUERRERO et al., 2016). Therefore, the increased micronutrient accumulation for plants growing on Sitreated soils is likely a result of decreased competition between $\mathrm{Cd}$ and micronutrients owing to Si effects on $\mathrm{Cd}$ solubility, as previously discussed.

\section{CONCLUSION}

Our results showed that $\mathrm{Si}$ applied as a diatomaceous Earth fertilizer improves biomass and nutrient accumulation $(\mathrm{N}, \mathrm{K}, \mathrm{Ca}, \mathrm{Mg}, \mathrm{Fe}, \mathrm{Mn}, \mathrm{Cu}$, and $\mathrm{Zn}$ ) of maize plants grown on a Cd-contaminated soil. The Si application to soil and the liming had a positive effect on biomass and nutrient uptake, but the Si effect on plants' performance took place irrespectively to the soil $\mathrm{pH}$. Silicon ameliorated $\mathrm{Cd}$ phytotoxicity in both limed and non-limed soils by decreasing $\mathrm{Cd}$ concentration in shoots; $\mathrm{Si}$ alleviation of Cd-inhibitory effects on plants was more effective in the non-limed soil owing to the higher $\mathrm{Cd}$ availability in acidic soils. Considering the reduced transfer of $\mathrm{Cd}$ to shoots driven by $\mathrm{Si}$, lower $\mathrm{Cd}$ accumulation in maize grains is likely, with implications to food safety. 

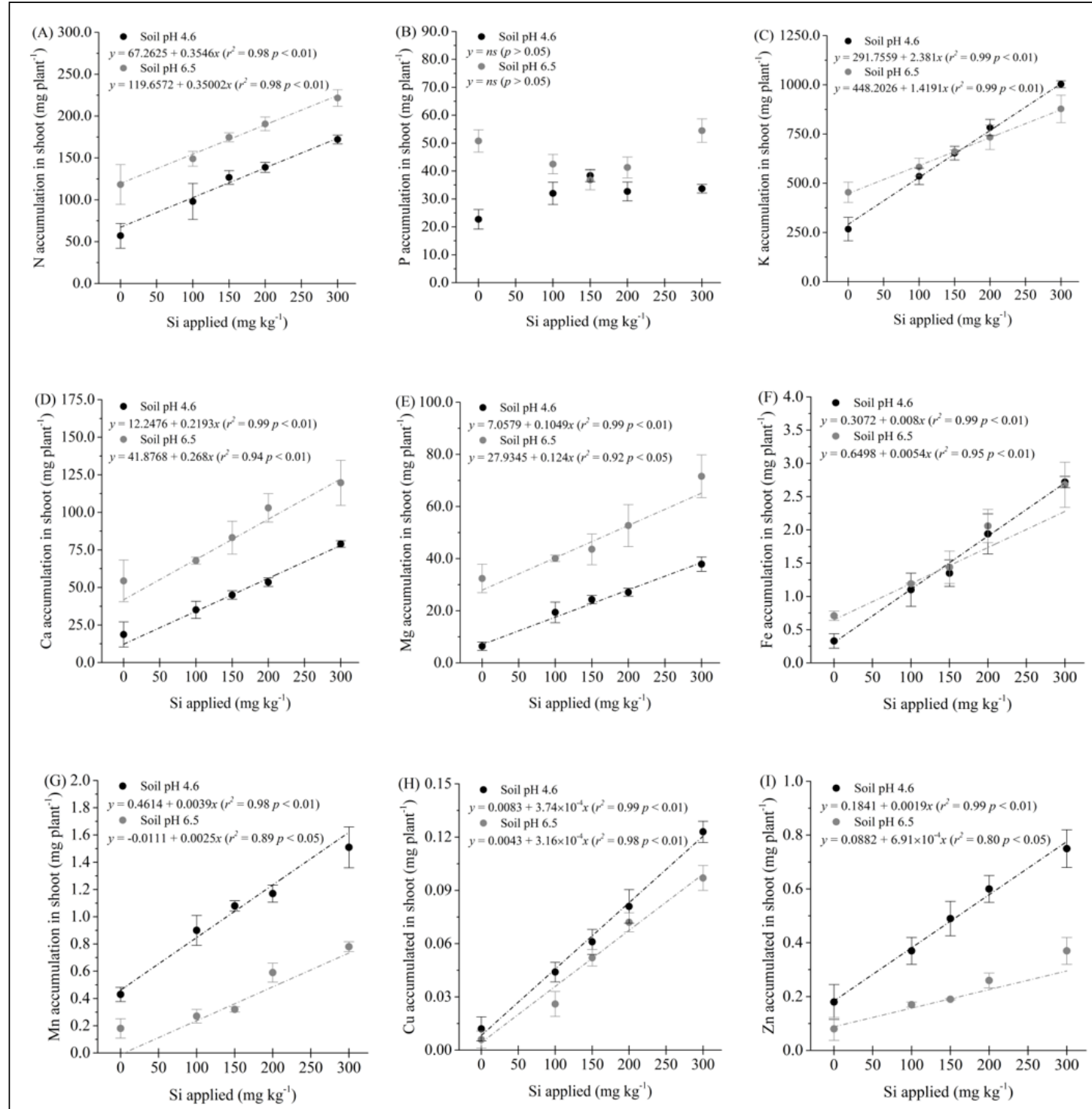

Figure 5 - Nutrient accumulation in shoot of maize plants grown on an $\mathrm{Cd}$ - contaminated soil with or without $\mathrm{pH}$ correction as a function of silicon doses applied to soil.

\section{ACKNOWLEDGEMENTS}

C.W.A. do Nascimento is grateful to the Conselho Nacional de Desenvolvimento Científico e Tecnológico (CNPq) for a research productivity scholarship (Proc. 305782/2018-5). V. L. Veloso is recipient of a doctoral scholarship (Proc. 131921/20185) from the Conselho Nacional de Desenvolvimento Científico e Tecnológico (CNPq). J. R. Silva acknowledges the Fundação de Amparo à Ciência e Tecnologia do Estado de Pernambuco (FACEPE) for a doctoral scholarship (IBPG 0652-5.01/17). F. B V. Silva is grateful to the Coordenação de Aperfeiçoamento de Pessoal de Nível Superior (CAPES) and Fundação de Amparo à Ciência e Tecnologia do Estado de Pernambuco (FACEPE) for a postdoctoral fellowship (PNPD/CAPES) (BCT-0296-5.01/18).

\section{DECLARATION OF CONFLICT OF INTERESTS}

The authors declare no conflict of interest. The founding sponsors had no role in the design of the study; in the collection, analyses, or interpretation of data; in the writing of the manuscript, and in the decision to publish the results.

\section{AUTHORS' CONTRIBUTIONS}

All authors contributed equally for the conception and writing of the manuscript. All authors critically revised the manuscript and approved of the final version. 


\section{REFERENCES}

ATSDR. ATSDR's Substance Priority List, Atlanta, 2017 Online. Available from: $<$ https://www.atsdr.cdc.gov/spl/\#2017sp $>$. Accessed: Apr. 29, 2019.

CUNHA, K. P. V. et al. Cadmium and zinc availability, accumulation and toxicity in maize grown in a contaminated soil. Revista Brasileira de Ciencia do Solo, v.32, n.3, p.1319-1328, 2008. Available from: <http://ref.scielo.org/qfdm8z>. Accessed: Feb. 20, 2019. doi: 10.1590/S0100-06832008000300039.

CUNHA, K. P. V.; NASCIMENTO, C. W. A. Silicon effects on metal tolerance and structural changes in maize (Zea mays L.) grown on a cadmium and zinc enriched soil. Water, Air, and Soil Pollution, v.197, n.1, p.323 2009. Available from: $<$ https://rdcu.be/ bTfLn>. Accessed: Apr. 5, 2019. doi: 10.1007/s11270-008-9814-9.

GARG, N.; SINGH, S. Arbuscular mycorrhiza Rhizophagus irregularis and silicon modulate growth, proline biosynthesis and yield in Cajanus cajan L. Millsp. (pigeonpea) genotypes under cadmium and zinc stress. Journal of Plant Growth Regulation, v.37, n.1, p.46-63 2018. Available from: <https://doi.org/10.1007/ s00344-017-9708-4>. Accessed: Apr. 20, 2019. doi: 10.1007/ s00344-017-9708-4.

GONZÁLEZ-GUERRERO, M. et al. Transition metal transport in plants and associated endosymbionts: arbuscular mycorrhizal fungi and rhizobia. Frontiers in Plant Science, v.7, p.1088, 2016 Available from: <http://journal.frontiersin.org/Article/10.3389/ fpls.2016.01088/abstract>. Accessed: Apr. 18, 2019. doi: 10.3389/ fpls.2016.01088.

JANICKA-RUSSAK, M. et al. Different effect of cadmium and copper on $\mathrm{H}+$-ATPase activity in plasma membrane vesicles from Cucumis sativus roots. Journal of Experimental Botany, v.63, n.11, p.4133-4142, 2012. Available from: <https://academic.oup. com/jxb/article/63/11/4133/601130>. Accessed: Apr. 21, 2019. doi: $10.1093 / \mathrm{jxb} / \mathrm{ers} 097$.

KEEPING, M. G. et al. Liming an acid soil treated with diverse silicon sources: Effects on silicon uptake by sugarcane (Saccharum spp. hybrids). Journal of Plant Nutrition, v.40, n.10, p.14171436, 2017. Available from: <https://www.tandfonline.com/doi/ abs/10.1080/01904167.2016.1267751>. Accessed: Feb. 20, 2019 doi: $10.1080 / 01904167.2016 .1267751$.

KIRKHAM, M. B. Cadmium in plants on polluted soils: effects of soil factors, hyperaccumulation, and amendments. Geoderma, v.137, n.1, p.19-32, 2006. Available from: <https://www. sciencedirect.com/science/article/abs/pii/S0016706106002540>. Accessed: Jul. 22, 2020. doi:. 10.1016/j.geoderma.2006.08.024

KORNDÖRFER, G. H. et al. Calcium and magnesium silicates in agriculture. Boletim Técnico, 2004. v.2, p.1-31

KORNDÖRFER, G. H.; Coelho, N. M.; Snyder, G. H.; Mizutani, C. T. Evaluation of soil extractants for silicon availability in upland rice. Revista Brasileira de Ciência do Solo, v.23, p.101106, 1999. Available from: <http://dx.doi.org/10.1590/S010006831999000100013>. Accessed: Jul. 22, 2020.

LAMB, D. T. et al. Predicting plant uptake of cadmium: validated with long-term contaminated soils. Ecotoxicology, v.25, n.8, p.1563-1574, 2016. Available from: <https://rdcu.be/bS5Jx >. Accessed: Apr. 18, 2019. doi: 10.1007/s10646-016-1712-0.
NASCIMENTO, C. W. A. et al. Influence of silicon fertilization on nutrient accumulation, yield and fruit quality of melon grown in northeastern Brazil. Silicon, p.1-7, 2019. Available from: <http:// link.springer.com/10.1007/s12633-019-00187-5>. Accessed: Apr. 18, 2019. doi: 10.1007/s12633-019-00187-5.

PALMER, C.; GUERINOT, M. L. Facing the challenges of $\mathrm{Cu}, \mathrm{Fe}$ and $\mathrm{Zn}$ homeostasis in plants. Nature chemical biology, v.5, n.5, p.333-340, 2009. Available from: <https://www.nature.com/articles/ nchembio.166>. Accessed: Apr. 20, 2019. doi: 10.1038/nchembio. 166.

REHMAN, M. Z. Ur. et al. Split application of silicon in cadmium (Cd) spiked alkaline soil plays a vital role in decreasing $\mathrm{Cd}$ accumulation in rice (Oryza sativa L.) grains. Chemosphere, v.226, p.454-462, 2019. Available from: <https://www.sciencedirect. com/science/article/pii/S0045653519306289>. Accessed: Apr. 18, 2019. doi: 10.1016/j.chemosphere.2019.03.182.

SHAREEF, R. S. et al. The accumulation of cadmiun in corn (Zea Mays L.) at different levels of soil pH. American Journal of Microbiology and Immunology, v.1, n.1, p.20-29, 2016. Available from: <https://escipub.com/shareef-ajmi-08-2016/>. Accessed: Jul. 18, 2020.

SILVA, A. J. et al. Assessment of cadmium phytotoxicity alleviation by silicon using chlorophyll $a$ fluorescence. Photosynthetica, v.55, n.4, p.648-654, 2017. Available from: <https://link.springer. com/article/10.1007\%2Fs11099-016-0680-1>. Accessed: Apr. 22, 2019. doi: 10.1007/s11099-016-0680-1.

SILVA, F.C.S. et al. Manual de análises químicas de solos, plantas e fertilizantes. Brasília, DF : Embrapa Informação Tecnológica, 2009. 2v.

USEPA. United States Environmental Protection Agency. 2002. Complying with the revised drinking water standard for arsenic: small entity compliance guide United States Environmental Protection Agency, Office of Ground Water and Drinking Water. [Online WWW]. Available from: <http://www.epa.gov/safewater/ arsenic/pdfs/ars_final_app_f.pdf $>$. Accessed: Apr. 22, 2020.

VACULÍK, M. et al. Silicon modifies root anatomy, and uptake and subcellular distribution of cadmium in young maize plants. Annals of Botany, v.110, n.2, p.433-443, 2012. Available from: $<$ https://doi.org/10.1093/aob/mcs039>. Accessed: Apr. 10, 2019. doi: $10.1093 / \mathrm{aob} / \mathrm{mcs} 039$.

WANG, F. et al. In situ remediation of cadmium-polluted soil reusing four by-products individually and in combination. Journal of Soils and Sediments, v.14, n.3, p.451-461, 2014. Available from: <https:// link.springer.com/article/10.1007/s11368-013-0827-7>. Accessed: Apr. 22, 2019. doi: 10.1007/s11368-013-0827-7.

WANG, Y. et al. Silicon improves photosynthetic performance by optimizing thylakoid membrane protein components in rice under drought stress. Environmental and Experimental Botany, v.158, p.117-124, 2019. Available from: <https://www.sciencedirect. com/science/article/pii/S0098847218313649>. Accessed: Apr. 20, 2019. doi: 10.1016/j.envexpbot.2018.11.022.

YU, H. Y. et al. Cadmium availability in rice paddy fields from a mining area: The effects of soil properties highlighting iron fractions and pH value. Environmental Pollution, v.209, p.38-45, 2016. Available from: <https://www.sciencedirect.com/science/ article/pii/S0269749115301810>. Accessed: Apr. 20, 2019. doi: 10.1016/j.envpol.2015.11.021.

Ciência Rural, v.51, n.2, 2021. 